\title{
Virtual Ethnography Study of Inter-lecturer Communication in National Young Lecturers Forum WhatsApp Group
}

\author{
Nuning Kurniasih \\ Faculty of Communication Science \\ Universitas Padjadjaran \\ Bandung, Indonesia \\ nuning.kurniasih@unpad.ac.id
}

\author{
Teuku Riyadhsyah \\ Transportation Engineering Program \\ Politeknik Negeri Lhokseumawe \\ Lhokseumawe, Indonesia \\ riyadhsyah.teuku@pnl.ac.id
}

\begin{abstract}
Many lecturers use WhatsApp group chat to communicate, including the National Young Lecturers Forum/ Forum Dosen Muda Nusantara. This study aims to analyze the communication happened in FDMN WhatsApp group chat. This study based on virtual ethnography method. The informant chose using purposive sampling technique. In-depth interviews are done with three active members, two passive members, and one admin. Triangulation is done by method and data source triangulation, researcher's triangulation and theory triangulation. The results show the informants agree that the reason they join the group is to meet their information need, share information regards the profession of lecturer, get the chance to be acquainted with other lecturers from all around Indonesia, build a networking, and share information regarding the real condition of various universities in Indonesia; there were members joint the FDMN WhatsApp group by click the link that shared by members of FDMN WhatsApp group and there were also members added by the admin; information shared and discussed in the group focused on the lecturer matters related; the interaction happens in the group can be categorized into five categories of social interaction that is exchange, competition, cooperation, conflict, and coercion; FDMN WhatsApp group has the cognitive, affective, and behavior effects to the group members. The results of the study might contribute to the issue of effective alternative media for inter-lecturer communication.
\end{abstract}

Keywords - lecturers Communication, Social Media, Instant Messenger, Whatsapp

\section{INTRODUCTION}

WhatsApp is a current most popular instant messaging (IM) apps in Indonesia nowadays. ComScrore, a market research company, as cited by Bohang in Kompas claims that WhatsApp has the total of $77,6 \%$ market share of the mobile internet users with 35 million active users in Indonesia [1]. The popularity of WhatsApp is supported by the offered features, namely multimedia feature, group chat, unlimited messaging, cross platform engagement, offline messaging, no charges involved, also no pins and user name [2]. IM users are divided into two categories, heavy users and light users. The motives of IM heavy users for students are affection and sociability, where they need to meet new friends, to express affection, and to show concern to the others. Meanwhile, the motives of IM light users include fashion and entertainment, where they use IM to keep up with the trend and style [3].

WhatsApp group chat can be used for various purposes. For example, a study regards the use of WhatsApp group chat in supporting the medical personnel community in Malawi aimed to help the managerial works, to share health information and technical procedures, professional participation, to share personal life topic and humors, political debate, and culture in general [4]. In the case of family WhatsApp group chat, the significance of WhatsApp group is the openness of the members' characteristic and as the social support [5]. For the professionals, for instance the professionals in the field of Library and Information Sciences, WhatsApp considered as a vital communication media. They argue that the use of WhatsApp group as a discussion platform help them improve their professional skills set [6]. For lecturers, WhatsApp group chat can become an instructional media, information dissemination media, communication media, etc. Communication is a process of delivering messages, ideas, notions, thoughts, and feelings to others by oral, text, or verbal and nonverbal cues aimed to achieve similar understandings. Communication is the essence of an organization. Mortensen [7] argues that almost $70 \%$ of our time spent to communicate. The communication itself can be done face to face or through the media.

Many lecturers use WhatsApp group chat to communicate, including the National Young Lecturers Forum / Forum Dosen Muda Nusantara (later regarded as FDMN). The FDMN WhatsApp group chat created on May 3, 2016. This group initially created when one of the Indonesian Young Lecturers Forum / Forum Dosen Muda Indonesia (FDMI) Facebook group members questioned the group's WhatsApp chat. The Facebook group itself has changed name from FDMI to IDRI (Indonesian Lecturers Association / Ikatan Dosen Republik 
Indonesia). The WhatsApp group of FDMN has the maximal numbers of its members, which is 256 members, including young lecturers from both national and private university in Indonesia. To accommodate the members who cannot join the WhatsApp group, FDMN then created a group chat in Telegram. The communication dynamics in cyber world required us to review the understanding of interaction concept in virtual community [8].

The concept of Media Richness Theory or Information Richness Theory by Richard L. Daft and Robert H. Lengel in Computer-Mediated Communication (CMC) are very popular. This theory suggests that an organization needs a media with a richness level of message delivery. According to this theory media richness based on four sub dimensions that is the amount of signs system supported by media, feedback velocity from both sides simultaneously, supporting natural language, and message personalization. Furthermore, Social Presence Theory by John Short, Ederyn Williams, and Bruce Christie, suggests that each media communication has different capacities in transmitting non-verbal communication to confirm the verbal content. A media that capable to accommodate people's social and emotional presence, which can generate meaningful communication, is indeed an effective communication media [9]. Nevertheless, Social Influence Theory by Fulk, J., Schmitz J. Fulk and C.W. Steinfield denies the whole aspects of Media Richness Theory and Social Presence Theory. The Social Influence Theory argues that people chose media not only based on the media characteristics, but also based on the individual characteristics and the social context where the communication happened [10]. A Social Identity Model of Deindividualization Effects (SIDE) of CMC predicts that anonymity can improve the social influence when same group's identity protrudes [11].

This study aims to analyze the communication happened in FDMN WhatsApp group chat by answering several research questions regarding issues as follows: the purposes of young lecturers join FDMN WhatsApp group, how they join the WhatsApp group? How the members of FDMN WhatsApp group interact? Kind of information shared in FDMN WhatsApp group and the effects of FDMN WhatsApp group. The results of the study might contribute to the issue of effective alternative media for inter-lecturer communication.

\section{RESEARCH METHOD}

This study based on virtual ethnography method, in which WhatsApp group is the research site to gain details description on the inter-lecturer communication of FDMN members. Researcher needs to understand the whole points of virtual communication including space, time, authenticity, identity, and ethics [12]. The data collection of virtual ethnography is online based and from the virtual environment. The object of this study is the members of FDMN WhatsApp group. This group has maximum of 256 members and is increasing or decreasing when there is members left the group or deleted by the group admin. The informant chose using purposive sampling technique. In-depth interviews are done with three active members, two passive members, and one admin. One of the researchers is the original member and also one of the admins of FDMN WhatsApp group.
Triangulation is done by: (1) method and data source triangulation, by employing participatory observation in the FDMN WhatsApp group; (2) researchers triangulation, by comparing the field findings of each researcher; (3) theory triangulation, by comparing the field findings with the existing theory.

\section{RESULTS AND DISCUSSION}

\section{The Purposes of Young Lecturers Joining FDMN WhatsApp Group}

According to one of the admins, FDMN WhatsApp group initially created by Lek Dah because there were questions regarding the whatsapp group of Indonesian Lecturers Association (IDRI) Facebook group (used to named Indonesian Young Lecturers Forum/ FDMI). IDRI Facebook group itself was created to accommodate information needs of new young lecturers who do not know much regarding the profession as lecturer. During its development, IDRI Facebook group issued official member rules and collected member fee, which was burdensome for some of the existing group members. Thus, the members WhatsApp group agreed to establish National Association of Young Lecturers (Asosiasi Dosen Muda Nusantara/ ADMN) then it was changed to National Young Lecturers Forum/ Forum Dosen Muda Nusantara, a free of charge organization for the national young lecturers. At the beginning of its establishment, members of FDMN WhatsApp group focused to establish FDMN as an official organization.

The members actively discuss the name and requirements needed to be an official organization. Unfortunately, the establishment of this official organization is not yet accomplished because the first National Conference of FDMN, which was going to be held on August 2016, was cancelled. However, the informants agree the WhatsApp group is very useful and the reason they join the group is to meet their information need and share information regards the profession of lecturer.

Most of the informants admit that when they join a Facebook group where there are majority of senior or older lecturers, sometimes they felt discouraged and ignored because no one answer their questions in the group. Meanwhile, by joining FDMN WhatsApp group, they can get the information needed easily. Members of this group also share various important information regards lecturer. Besides, the members also get the chance to be acquainted with other lecturers from all around Indonesia, build a networking, and share information regarding the real condition of various universities in Indonesia. Although FDMN also creates a Facebook group, the WhatsApp group is still considered very significant. According to the informants, there are less people who access Facebook these days, thus WhatsApp group is considered very helpful in gaining information. The informant also admits there is a sense of emotional familiarity in WhatsApp group compares to Facebook group. There are various purposes of WhatsApp usage include helping managerial and technical matters, from serious to daily matters, such as humor [4]. 


\section{How the Young Lecturers Join FDMN WhatsApp Group}

According to the informant, initially the FDMN WhatsApp group consisted of a group of the apprentice lecturers of the Ministry of Research, Technology, and Higher Education of Indonesia (Kemenristekdikti) and a group of young single and cool lecturers, which used to form a WhatsApp group named "Dosen Muda Single Keren". The admin added the members of the two groups into FDMN WhatsApp group. The members then shared link or information they got from FDMN WhatsApp group to the other groups or personal messaging, which lead to more people want to join the FDMN WhatsApp group, and there were also members who added later by the admin. The similar background and willingness to join a group will eventually contribute in generating an effective communication.

\section{The Information or Messages in FDMN WhatsApp Group}

At the beginning of FDMN WhatsApp group's establishment the admin has explained to the members that the purpose of the group is to discuss the matters related to the profession of lecturer. Thus, information shared and discussed in the group focused on the lecturer matters related. The information including research information, which upload on the Research and Public Service Information System; human resource information related from the Directorate General of Information Resource and Technology; apprentice lecturer information; important announcements from the official twitter account of the Ministry of Research, Technology, and Higher Education of Indonesia; information regarding lecturer's rights and welfare; lecturer's complain, such as the difficulty of getting the national lecturer official number or known as NIDN, having a home base, how to raise one's functional degree, career level, and other rules related. The original sources of each information are from the official website and twitter account of the Ministry of Research, Technology, and Higher Education of Indonesia, Private High Education Coordinator (Kopertis), other WhatsApp groups and from amongst the lecturer.

Then, how about the hoax information? The WhatsApp group admin admits they only share information from official sources, thus there are no hoax information shared in the group. Moreover, other informants emphasize that lecturer is a well-educated person, which will always selecting information before sharing it. Thus, there is no hoax information shared in the group. However, two other informants admit that once they encountered with hoax information in the group, but then it was directly clarified by the correct information, thus it did not have a chance to get viral.

\section{Lecturers Interaction on FDMN WhatsApp Group}

Social interaction is a process involving action and reaction [13]. Social interaction is categorized into five categories that is exchange, competition, cooperation, conflict, and coercion. Social media and digital devices these days maintain the 'constant networked connection' within the individual's social networking [14]. This has totally changed the way people interact to each other [15]. At the beginning of its establishment, the members of FDMN WhatsApp group actively engaged in the discussion because they have similar interest, which was to establish an official organization for national young lecturers without annual fee needed or free. The membership of an official profession organization is a significant matter for the members of FDMN WhatsApp group since it will help increasing the accreditation points of their university. It is called as social exchange. After the discussion regarded the official organization establishment ended, discussion then shifted to various issues regard lecturer's activities and technical problems. The members of the group do not respond to all of the statements and questions addressed by the others. According to the informants, when a member addresses a question or attempts to open discussion regards a certain topic that have been discussed before, the members tend to ignore it. It is not necessarily a matter of competition, however it shows there is asymmetric information, particularly for the newbies in the group who do not follow the group development in the beginning. Some of the members chose to be silent readers and only participate in several interesting topics based on their personal interest. According to the informants, information regards lecturer's rights, welfare, complain, career level, functional degree increment, and educations are the most responded type of information. An informant admits that he follows the group development diligently, read all of the messages in the group, but only join the group discussion when his opinions needed. It shows the existence of cooperation in the group. Group members feel the urge to participate in the discussion when other needs their opinion or participation.

During the study, we informed the group members that we were conducting a research within the group and they support it by declaring their willingness to be the informant. The cooperation amongst the group members is not only exist in the WhatsApp group because in several areas the members hold meetings then followed by forming a discussion group offline. The members also use personal channel or direct message to address a question to or require further explanation from certain member. A conflict might happen in the group when a member shares information unrelated to the group theme. Entertainment information usually common for most of the members but few members does not welcome it since it considered unrelated to the group theme.

The members dislike information that discredits certain clan, race, religion, and political choice. When it happens, some of the members declare their dislike directly or through the group admins, and the other some only withstand it while judging every member's characters in the group. The fundamental matter of social media is people unable to control a message entirely, but they can contribute to the discourse [16].

There was a case when an admin did coercion by deleting some members who did not have same perspective as him. When this was happened, other members declare their objection of this arbitrary act and stir chaos in the group. The discussion then lead to a decision to add more admins in order to keep each other warned.

Some of the group members left the group because of various reasons, among others are the technical problem of their devices while the others refuse to tell the reason. This 
causes group members fluctuation, but when there is member left the group usually followed by other new member join in. Some informants spend 2 to 3 hours special to read the messages in the group, while some others read the messages directly whenever the notification comes in.

\section{The Effects of FDMN WhatsApp Group}

As mentioned before, the main reason of why young lecturers join the FDMN WhatsApp group is to gain information needed regarding lecturer. All of the informants agree the WhatsApp group is very useful. An informant admits to have archived all of the information he got from the WhatsApp group in order to be able to access it when needed. $\mathrm{He}$ also added that the information source in the group is usually from other members who actually have experienced it, thus it helps him to understand the issue rather than reading the manual or guidance book from the official source. By joining the group, the informants gain information needed (cognitive effect), able to empathize to other lecturer's problems (affective effect), able to share information and react upon it by doing certain action, such as managing the functional degree increment, NIDN, home base, become an apprentice lecturer, etc. (behavioral effect).

\section{CONCLUSION}

FDMN WhatsApp group has been used as the information and communication media amongst the young lecturers. The interaction happens in the group can be categorized into five categories of social interaction that is exchange, competition, cooperation, conflict, and coercion. FDMN WhatsApp group has the cognitive, affective, and behavior effects to the group members.

\section{ACKNOWLEDGMENT}

It is a research collaboration between $1^{\text {st }}$ author and $2^{\text {nd }}$ author with the help of the informant on the field. I would like to thank to Faculty of Communication Science Universitas Padjadjaran, members of FDMN Whatsapp Group and all of those involved for the support.

\section{REFERENCES}

[1] F. K. Bohang. "10 Aplikasi mobile terpopuler di Indonesia," 1 April 2017. [Online]. Available: http://tekno.kompas.com/read/2017/04/01/18240067/ 10.aplikasi.mobile.terpopuler.di.indonesia.

[2] S. Gon and A. Rawekar. "Effectivity of e-Learning through Whatsapp as a teaching learning tool," $M V P$ Journal of Medical Sciences, Vol 4(1), 19-25, pp. 19-25, 2017.

[3] S. LIN, "Instant messaging on interpersonal relationship: how it brings intimacy and negative feelings?" School of Journalism and Communication - The Chinese University of Hong Kong, Hongkong, 2012.

[4] C. Pimmer. "Using WhatsApp groups to support community health workers: preliminary insights from a pilot study in rural," 20 December 2015. [Online]. Available: www.christoph.pimmer.info/ DOI: 10.13140/RG.2.1.1450.5048.

[5] N. Aharony and T. Gazit. "The importance of the whatsapp family group: an exploratory analysis," Aslib Journal of Information Management, Vol. 68 Issue: 2, pp. 174-192, 2016.

[6] M. K. Bajpai, "Impact of WhatsApp on LIS professionals," Journal of Library \& Information Technology, Vol. 36, No. 6,, pp. 424-430, 2016.

[7] C. D. Mortensen, Communication theory, New Jersey: Transaction Publishers, 2011.

[8] D. Holmes, Communication theory, CA: Sage Publication Ltd, 2005.

[9] J. B. Walther. "Theories of computer mediated communication and interpersonal relations," in The Handbook of Interpersonal Communication , Thousand Oaks, CA, SAGE Publishing, 2011, pp. 443-479.

[10] S. J. Fulk and C. Steinfield, "A social influence of technology use," in Organization and unication Technology, 1990, pp. 117-142.

[11] T. Postmes, R. Spears, K. Sakhel and D. d. Groot, "Social influence in computer-mediated communication: the effects of anonymity on group behavior," Personality and Social Psychology Bulletin, p. 1243-1254, 2001.

[12] K. F. Steinmetz, "Message received: virtual ethnography in online message boards," International Journal of Qualitative Methods Vol 11, No 1, pp. 26-39, 2012.

[13] E. Goffman, The presentation of self in everyday life, London: Penguin, 1959.

[14] K. Burchell, Negotiating connecting without convention: the management of presence, time and networked technology in everyday life, London: Goldsmiths, University of London, 2012.

[15] B. Hogan, "The presentation of self in the age of social media: distinguishing performances and exhibitions online," Bulletin of Science, Technology \& Society Vol. 30 Issue 6, Sage Publications, pp. 377-386, 2010.

[16] T. D. Baruah, "effectiveness of social media as a tool of communication and its potential for technology enabled connections: a micro-level study," International Journal of Scientific and Research Publications, Volume 2, Issue 5, pp. 1-10, 2012.

[17] E. Goffman, Stigma: notes on the management of spoiled identity, Harmondsworth: Penguin Books, 1984.

[18] K. Sulting, Z. Mansor, S. Widyarto and N. H. A. Sukumar Lecthumunan, "Social media: how it ensures effective communication," Recent Advances in Computer Science, pp. 222-227, 2015.

[19] S. R. Beauchamp and S. J. Baran, Introduction to 
human communication: perception, meaning, and identity, Oxford: Oxford University Press, 2015.

[20] K. Miller, Communication theories: perspectives, processes, and contexts, New York: McGraw-Hill Higher Education, 2004.

[21] J. N. Bailenson, N. Yee, J. Blascovich and R. E. Guadagno, "Transformed social interaction in mediated interpersonal communication," in Mediated Interpersonal Communication, London, Routledge, 2008, pp. 77-99.

[22] S. Crichton and S. Kinash, "Virtual ethnography: interactive interviewing online as method," Canadian Journal of Learning and Technology Volume 29(2) Spring / printemps 2003, 2003.

[23] N. G. Fielding, R. M. Lee, G. Blank and F. Nigel G., The SAGE handbook of online research methods,
Los Angles, London, New Delhi, Singapore: SAGE Pub, 2008.

[24] C. Hine, Virtual ethnography, London, Thosands Oaks, New Delhi: SAGE Publications, 2000.

[25] S. J. Tracy, Qualitative research methods: collecting evidence, crafting analysis, communicating impact, UK: Wiley-Blackwell, 2013.

[26] K. O'Sullivan, Understanding ways: communication between cultures, NSW: Southwest Press P/L, 1997. 